\title{
PHYTOPHAGOUS ENTOMOFAUNA OCCURRING ON ONION PLANTATIONS IN POLAND IN YEARS 1919-2007
}

\author{
Jerzy SZWEJDA, Robert WRZODAK \\ Research Institute of Vegetable Crops \\ Konstytucji 3 Maja 1/3, 96-100 Skierniewice, Poland
}

Received: February 6, 2009; Accepted: September 21, 2009

\section{Summary}

In years 1919-2007 on domestic onion plantations 37 phytophagous species taxons belonging to 7 insect orders: Thysanoptera, Homoptera, Heteroptera, Lepidoptera, Coleoptera, Diptera and Orthoptera were noted. Among these groups 22 species were stated as phytophagous, additional taxons were indentified to 5 genus (Thrips, Mamestra, Polia, Agrotis, Agriotes) and 3 families: fungus gnats (Sciaridae), march flies (Bibionidae), crane flies (Tipulidae). Furthermore 7 species of saprophagous Diptera were collected from damaged onions during harvest.

The most common dominant species occurring in all regions of onion production were: onion fly (Delia antiqua Meig.), onion thrips (Thrips tabaci Lind.), onion weevil (Ceutorhynchus suturalis Fabr.), leek moth (Acrolepiospis assectella Zell.) and cutworms (Noctuidae). The population density of: onion beetle (Lilioceris merdigera L.), garlic fly (Suillia lurida Meig.) and leek miner fly (Napomyza gymnostoma Loew) were only a seasonal danger, especially in southern regions of Poland. On wet and rich in organic matter soils some soil dwelling insects such as larvae of Melolontha species (Scarabaeidae), larvae of Agriotes (Elateridae), flies (Diptera) from Tipulidae and Bibionidae families were also occurring periodically.

The species and population changes of above mentioned pests allowed to elaborate effective pest control methods of onion plantations. The pest control was performed after field monitoring on the basis of constantly updated short and long-term forecasting.

key words: entomofauna of onion: Diptera, Lepidoptera, Coleoptera, Thysanoptera, Homoptera, Heteroptera, Orthoptera

\section{INTRODUCTION}

In the field of vegetable production majority of papers concerns research on most commonly occurring pest species causing serious and economically important losses. The occurrence of phytophagous species on single vegetable 
crops has not been yet described as a full description in a monographic paper. The same problem applies to injurious fauna of onion crops. The constant monitoring of pest occurring on domestic vegetable plantations started in 1919 and it was constantly carried out afterwards by plant protection services. Up to the present moment only pest species occurring on spring planted onion crops have been registered (Ruszkowski 1933, Ruszkowski et al. 1935, Szwejda 2006 $\mathrm{a}, \mathrm{b})$. Due to the climate change with warmer winters the area of autumn planted onion crops is extending. Observations performed so far shows that there are important changes in dominant phytophagous species population due to extended vegetation period in autumn and also in early spring planted onion crops. (Szwejda 2005b). It especially concerns onion thrips (Thrips tabaci) which population density depends on the time of autumn onion sowing (Wrzodak 2008).

In years 1919-2007 on domestic onion plantations there have been no major changes in pest species composition. However, the analysis of long-term observations have shown major quantitative differences in registered phytophagous species. Some species such as: Lilioceris merdigera, Eumerus tuberculatus, Hydrellia griseola only occurred sporadically and are not currently registered as pests (Ruszkowski 1933, Ruszkowski et al. 1935, Kuntze 1936, Hennig 1953, Osmołowski 1980, Szwejda 2005a).

\section{CLASSIFICATION AND FREQUENCY OCCURRING OF PHYTOPHAGOUS ENTOMOFAUNA ON ONION PLANTATIONS}

In the discussed period of time on onion plantations 37 phytophagous species taxons representing 7 insect orders: Diptera, Lepidoptera, Coleoptera, Thysanoptera, Homoptera, Heteroptera and Orthoptera were noted. Among these groups 22 species were stated as phytophagous, additional taxons were indentified to 5 genus (Thrips, Mamestra, Polia, Agrotis, Agriotes) and 3 families: fungus gnats (Sciaridae), march flies (Bibionidae), crane flies (Tipulidae). Furthermore 7 species of saprophagous Diptera were collected from damaged onions during harvest (Table 1).

All insects were collected from production farms all around Poland in years 1919-2006 from damaged parts of plants in the first and in the second year of onion vegetation.

Only species which life cycle is connected with onion crops as a larvae and pupae were taken into account. Later on into the adult stages, there were identified.

Collected species were divided into three groups based on the presence frequency and economic importance as pests (Table 1).

Group A: species occurring on onion in large numbers causing significant economic losses.

Group B: commonly occurring species which may cause damages locally.

Group C: sporadically occurring species - potential pests. 
PHYTOPHAGOUS INSECT SPECIES RECORDED ON ONION FIELDS IN 1919-2007

\begin{tabular}{|c|c|c|}
\hline Order & Species & $\begin{array}{c}\text { Frequency } \\
\text { of occurring }\end{array}$ \\
\hline \multirow[t]{2}{*}{ Thysanoptera } & Thrips tabaci Lind. & A \\
\hline & Thrips spp. & B \\
\hline \multirow[t]{2}{*}{ Heteroptera } & Carpocoris fuscipinus Boh. & $\mathrm{C}$ \\
\hline & Dolycoris baccarum L. & $\mathrm{C}$ \\
\hline \multirow[t]{2}{*}{ Homoptera } & Nectarosiphon ascalonicus Donc. & $\mathrm{C}$ \\
\hline & Trioza brassicae Vas. & $\mathrm{C}$ \\
\hline \multirow[t]{4}{*}{ Lepidoptera } & Acrolepiopsis assectella Zell. & A \\
\hline & Margarita stricticalis L. & $\mathrm{C}$ \\
\hline & Mamestra, Polia spp. & $\mathrm{C}$ \\
\hline & Noctuidae-Agrotis spp. & A \\
\hline \multirow[t]{6}{*}{ Coleoptera } & Ceutorhynchus suturalis Fabr. & A \\
\hline & Lilioceris merdigera $\mathrm{L}$. & A \\
\hline & Elateridae, Agriotes, Athous spp., & B \\
\hline & Scarabaeidae - Melolontha spp.: & \\
\hline & M. melolontha $\mathrm{L}$. & B \\
\hline & M. hippocastami Fabr. & $\mathrm{B}$ \\
\hline \multirow[t]{21}{*}{ Diptera } & Delia antiqua Meig. & A \\
\hline & D. platura Rond. & $\mathrm{C}$ \\
\hline & D. florilega Zett. & $\mathrm{C}$ \\
\hline & Suillia lurida Meig. & B \\
\hline & Eumerus strigatus Fall. & A \\
\hline & E. tuberculatus Rond. & $\mathrm{C}$ \\
\hline & Napomyza gymnostoma Loew & B \\
\hline & Liriomyza cepae Hend. & $\mathrm{C}$ \\
\hline & Phytomyza atricornis Loew & $\mathrm{C}$ \\
\hline & Chromomatomyia horticola Gour. & $\mathrm{C}$ \\
\hline & Hydrellia griseola Fall. & $\mathrm{C}$ \\
\hline & Sciaridae & $\mathrm{C}$ \\
\hline & Bibionidae & $\mathrm{C}$ \\
\hline & Tipulidae & $\mathrm{C}$ \\
\hline & Dorsilopha busckii Coqu.* & $\mathrm{A}^{*}$ \\
\hline & Fannia canicularis L.* & $\mathrm{A}^{*}$ \\
\hline & F. scalaris Fabr.* & $\mathrm{A}^{*}$ \\
\hline & F. leucostica Meig. * & $\mathrm{B}^{*}$ \\
\hline & F. manicata Meig.* & $\mathrm{B}^{*}$ \\
\hline & Muscina assimilis Fall.* & $\mathrm{A}^{*}$ \\
\hline & M. stabulans Fall.* & $\mathrm{A}^{*}$ \\
\hline Orthoptera & Gryllotalpa gryllotalpa L. & $\mathrm{C}$ \\
\hline
\end{tabular}

* saprophagous species

Group A : species occurring on onion in large numbers requiring control.

Group B : commonly occurring species which may cause damages locally.

Group C : sporadically occurring species - potential pests. 


\section{RESULTS AND DISCUSSION}

Onion crops as an important part of agrocenosis are a natural environment for many insect populations, not only phytophagous but also sapro- i zoophagous species (Tischler 1965, Crüger 1991, Szwejda 2003).

Phytosaprophagous entomofauna showed in table 1 is eurytopic, oligoand polyphagous and furthermore commonly occurs in the area of Palearctic region. Beside onion crops they are also present in other agrocenosis as well as in non- farm areas (wild growing species reservoirs, fallows, parks and woods). Onion crops were attacked by pests from the beginning of onion production in Poland and the oldest note concerning pests on vegetable crops applies to onion fly (Delia antiqua) causing damages on onion patches (Belke 1861).

\section{Flies (Diptera)}

Flies is a very rich group of insects both in species and individual. Adults of discussed species are melitophagous, they mainly feed on flower nectars, plant juices, liquids of live or dead plants or animals. They take part in flowers pollination and transport of other organisms such as Acari. They are themselves a source of food for many insectivorous species and pathogenic organisms. However, the trophic structure of pests larvae mentioned in Table 1 is significantly differentiated. They are endophagous and they feed inside soft plant tissue.

Larvae of majority of mentioned pests such as: onion fly (D. antiqua), bean seed flies (D. platura and D. florilega; Anthomyiidae) and onion bulb fly (Eumerus strigatus; Syrphidae) are phytosaprophagous. The most dominant phytophagous species among flies is onion fly (Delia antiqua). This species is widely distributed in Palearctic, from Japan throughout Asia and Europe, including Poland, northern Africa and America, to Alasca. In all mentioned regions the population of this pest is at the level which requires controlling. Depending on the latitude there is a difference in the number of generations of onion fly $(D$. antiqua) per year. In Norway there is only one generation per year (Rygg 1960), in the Netherlands there may be 2 to 3 generations (Loosjes 1976), in Poland there are 2 generations of onion fly per year (Szwejda 1982), whilst in Austria there were noted 3 to 4 generations (Schreier 1953). There are several factors influencing the number of generations: weather conditions (temperature, air and soil humidity, the length of the day), access to host plants, the number of natural enemies. Even though climatic conditions in mentioned countries are similar and the distance between them is slight the above factors are significantly influencing the number of pest generations. In the last decade in Poland changes in weather such as longer autumn and warm winters have also been observed. Extended vegetation period of grown onion crops and favourable environment conditions may induce next generation adults flight by interrupting diapause. The same factors may induce the number of onion fly generations in Poland, including the presence of the third one. The changes in onion production technology such as new varieties requiring different lenth of growing period and irrigation systems may also influence the number of pest 
generations. In the last few years the extension in overwinter onion production (from autumn sowing) has been observed. The results of observations performed so far show that the harmfulness of flies in autumn is rather significant up to $10 \%$ of damaged plants (Szwejda 2005b). The higher plants infestation by flies is also closely connected with plants health. The females of flies are more likely to lay eggs on plants formerly attacked by plant pathogens (Hausmann, Miller 1989). On onion and garlic plantations other species of flies may also commonly occur: D. platura and D. florilega (Ruszkowski et al. 1935, Finlayson 1956, Loosjes 1976, Szwejda 2003). The popular phytosaprophagous species which larvae feeds on damaged onion tissue is a onion bulb fly $(E u$ merus strigatus) (Ruszkowski 1933, Schreier 1953, Szwejda 2003). In years of massive occurrence at the time of onion ripening the population of lesser bulbfly may be even higher than that of onion fly (Szwejda 1998). Very little is still known about leaf miners (Agromyzidae), even though they are quite common in agrocenosis. Among several species belonging to this group the best known is leek miner fly (Napomyza gymnostoma), which has been harmful to onion and leek crops not that long (from 90.) (Sionek 2001). Larvae of leek miner fly feed inside mid-leaves what causes plant death (Sionek 1998). Leaves of onion crops are also attacked by polyphagous leaf-miner flies species such as Phytomyza atricornis and Chromatomyia horticola, which are common in agricultural areas but are not especially danger to onion crops (Ruszkowski 1933, Osmołowski 1980). The range of occurrence of onion leaf miner (Liriomyza (Phytobia) cepae) in Poland is not fully known, even though it is known as an onion pest in Germany (Hennig 1953, Crüger 1991). The species migrating from southern to northern Europe is garlic fly (Suillia lurida) from Helomyzidae family. In Poland it was first noted in 70 . of the last century in numbers causing $70 \%$ damages of garlic crops in autumn production (Szwejda 1988). In recent years $S$. lurida is also appearing on overwinter onion plantations from autumn sowing (Szwejda 2005b).

On wet and rich in organic matter soils onion bulbs are also damaged by march flies (Bibionidae) and crane flies (Tipulidae) larvae. They are phytosaprophagous and also present on non-agricultural lands (Ruszkowski 1933, Mikołajczyk 1981, Clements 1984, Mrówczyński et al. 2006).

Saprophagous species were a big part among all diptera flies occurring on onion crops. Onions in the early stage of phonological development is attacked by phytophagous species, but later on numerous saprophagous species also appear. Saprophagous species females are attracted to lay eggs by damaged and deteriorating plant tissues, where larvae are developing. In conducted longterm experiments they made up $42 \%$ of all collected diptera flies in the vegetation season (Szwejda 2003). Among saprophagous flies shown in Table 1 (marked with a star) the most numerous were species belonging to: muscids Fannia (Muscidae) and drosophilids - Dorsilopha (Drosophilidae), including D. busckii which may damage onion seeds. They commonly inhabit various crops agrocenosis, especially numerously on onion, garlic and Brussels sprout crops (Szwejda 2003). 


\section{Butterflies and Moths (Lepidoptera)}

Butterflies and moths are not as numerous as Diptera flies on onion plantations, but they are a significant importance. The most dangerous pest is leek moth (Acrolepiospis assectella) developing in Poland 2-3 generations. In Palearctic region it has been inhabiting onion crops for many years (Ruszkowski 1933, Osmołowski 1980). Likewise onion fly (Delia antiqua), weather and environment conditions have a crucial influence on the number of pest generations. Larvae of the first generation of $A$. assectella damage only onion leaves whilst next generations also injure flowers and seeds (Szwejda 1998) as well as impede overwinter onion germination (Szwejda 2005b). Among phytophagous eudominants of onion crops there is a number of cutworms (Noctuidae). They are polyphagous and the most numerous are species of cutworms - Agrotis: A. segetum Schiff., A. exclamationis L. and A. ypsilon Rott. (Ruszkowski 1933, Napiórkowska-Kowalik 1996). In years 2004-2005 on vegetable crops the dominant species was $A$. segetum and it made up over $90 \%$ of all caught larvae (Rogowska \& Wrzodak 2006). In recent years on onion leaves until the time of chive bending Mamestra sp. were also observed, especially cabbage moth (Mamestra brassicae L.).

In faunistical papers other species of butterflies are noted as polyphagous and mentioned as species occurring on onion crops only temporarily i.e.: the meadow moth (Loxostege sticticalis L.) (Ruszkowski 1933, Osmołowski 1980).

\section{Beetles (Coleoptera)}

Beetles are a significant part of phytophagous entomofauna of onion crops. The species of economic importance is onion weevil (Ceutorhynchus suturalis). It is especially harmful for onion in the early stage of development (germination) (Ruszkowska 1952, Osmołowski 1980, Szwejda 2005b). This species is antagonistic to leek moth (Acrolepiospis assectella) due to the fact that they occur on same host plants, where they are both eurytopic. In years 1970-2000, leek moth (A. assectella) was definitely dominating but it recent years in many regions of onion production the most numerous was onion weevil (C. suturalis) and the population of leek moth completely disappeared. This phenomenon is repetitive in cycles and it was observed in 30. of last century (Ruszkowska 1952). Onion beetle (Lilioceris merdigera) also appears periodically. Population of this species on plantations in central Poland was rather small in the last decade and was not significantly harmful (Szwejda 1998) comparing to 30. of last century when it was colonizing onion crops in large numbers (Kuntze 1936). In recent years in the southern Poland the population of Lilioceris merdigera stays at the level which requires controlling (Wiewióra \& Łuczak 2001). Alike in other agrocenosis periodic threat are also polyphagous beetles, wireworms (larvae of Agriotes sp.) and grubs (larvae of May beetles from Scarabaeidae family i.e.: Melolontha: M. melolontha and M. hippocastani) (Ruszkowski 1933, Sądej et al. 2003, Mrówczyński et al. 2006). They are usually occurring in large numbers and they completely damage underground parts of onions. 


\section{Thrips (Thysanoptera)}

Thrips is rich in species and numerous insect order commonly occurring in agrocenosis (Zawirska 1994). Onion thrips (Thrips tabaci) is the dominant species on vegetable plantations and its number usually exceeds the state of damage level on onion, leek and white head cabbage plantations (Szwejda 2005a). This species is cosmopolitan, polyphagous and it has been occurring in agrocenosis on all continents for many years (Balachowsky \& Mensil 1936). In the early stage of germination (1-2 leaves) chive is damaged by thrips adults and later on, in favourable weather conditions larvae are inhabiting plants in large numbers before forming and development of onion bulbs. Damages caused in this time are influencing the yield size. The presence of 10 thrips per plant at the time of onion bulb forming was decreasing the size of crop by 2$3 \%$. It was noted that the presence of 150-170 specimens per plant was declining the yield level by $34-43 \%$ (Kendall \& Capinera 1987). The threshold level for thrips damage has been determined by Fournier et al. (1995) as 0.9-2.2 specimens per leaf. The population density of thrips on overwinter onion crops significantly depends on the time of sowing.

On seed plantations, apart from chive T. tabaci is feeding inside inflorescence what in consequence is causing seed malformation (Osmołowski 1980). Onion crops are also attacked by other thrips species i.e.: T. angusticeps Uzel and T. denticornis Holiday (Crüger 1991).

\section{Other phytophagous species occurring on onion}

In the first and second year of cropping during growing season onion is also attacked by other than mentioned above phytophagous species. They are currently occasional and occur in low numbers which are not a threat to onion plantations. Among sporadic pest of onion crops are: European mole cricket (Gryllotalpa gryllotalpa) - polyphagous species feeding in plant root system (Ruszkowski et al. 1935), shallot aphid (Nectarosiphon ascalonicus) and brassica psyllid (Trioza brassicae) damaging leaves (Osmołowski 1980, Crüger 1991 ) as well as hairy shieldbug (Dolycoris baccarum) and Carpocoris fuscispinus damaging onion seeds (Osmołowski 1980).

\section{CONCLUSIONS}

1. The observations of harmful entomofauna of onion crops carried out in years 1919-2007 in the whole country showed that there are 30 phytophagous species and families present being represented by 7 insect orders: Thysanoptera, Homoptera, Heteroptera, Lepidoptera, Coleoptera, Diptera and Orthoptera.

2. The population of collected phytophagous entomofauna was stable regarding species composition during the time of observations in years 19192007, however the changes in single species population numbers were highly differentiated. 
3. Dominant species commonly occurring on plantations in Poland are: onion thrips (Thrips tabaci), onion weevil (Ceutorhynchus suturalis), leek moth (Acrolepiospis assectella), onion fly (Delia antiqua), garlic fly (Suillia lurida), leek miner fly (Napomyza gymnostoma), onion beetle (Lilioceris merdigera) and noctuid moths (Noctuidae).

4. The species and population changes of above mentioned pests allowed to elaborate effective pest control methods of onion plantations. The pest control was performed after field monitoring on the basis of constantly updated short- and long-term forecasting.

\section{REFERENCES}

Balachowsky A., Mensil L. 1936. III. Thysanoptéres, p. 1569-1576. Les insecticides aux plants cultivées. Paris. p.: 1-1921. [in French]

Belke G. 1861. O owadach szkodliwych gospodarstwu wiejskiemu i o sposobach ustrzeżenia się od nich lub zmniejszenia ich liczby. Wyd. Jan Husarski, Zytomierz: 174-328. [in Polish]

Clements R.O. 1984. Control of insect pests in Grassland. Span 27/2/: 77-79.

Crüger G. 1991. Gewürz und Küchenkräuter. Pflanzenszchutz im Gemusebaum. V. Eugen Umler pp. 334. [in German].

Finlayson D.G. 1956. Maggots and puparia in stems and seed balls of onion at harvest. J. Econ. Ent. 49(4): 460-462.

Furnier F., Boivin G., Stewart R.K. 1995. Effect of Thrips tabaci (Thysanoptera: Thripidae) on yellow onion yields and economic thresholds for its management. J. Econ. Ent. 88(5): 1401-1407.

Hausman S.M., Miller J.R. 1989. Ovipositional preference and larval survival of the onion maggot (Diptera: Antomyiidae) as influence by previous maggot feeding. J. Econ. Entomol. 82/2/: 426-429.

Hennig W. 1953. Diptera, Zwieflügler. Handbuch der Pflanzenkrankheiten, Berlin, 5: 1-166. [in German]

Kendall D.M., Capinera J.L. 1987. Susceptibility of onion growth stages to onion thrips (Thysanoptera: Thripidae) damage and mechanical defoliation. Environm. Entomology 16(4): 859-863.

Kuntze R. 1936. Krytyczny przegląd szkodników z rzędu chrząszczy, zarejestrowanych w Polsce w latach 1919-1933. Roczn. Ochr. Roślin 3/2/ 1-116. [in Polish]

Loosjes M. 1976. Ecology and genetic control of the onion fly, Delia antiqua (Meigen). Agric. Res., Inst. Phyt. Res., Wageningen, pp.179.

Mikołajczyk W. 1981. [Bibionidae (Diptera).] Fragmenta Faunistica, Inst. Zool. Warszawa 26/23/: 393-397. [in Polish with English summary]

Mrówczyński M., Wachowiak H., Pruszyński S. 2006. [New endangerment of agricultural crops by soil pests]. Progress Plant. Prot./Post. Ochr. Roślin, Poznań 46/1/: 300-304. [in Polish with English summary]

Napiórkowska-Kowalik J. 1996. Sówkowate (Lepidoptera, Noctuidae) i ich parazytoidy w agrocenozach rejonu Lublina. Rozpr. habil. Wyd. AR Lublin 194: 1-93. [in Polish]

Osmołowski G. 1980. Klucz do oznaczania szkodników na podstawie uszkodzeń roślin uprawnych. PWRiL, Warszawa, pp.755. [in Polish] 
Rogowska M., Wrzodak R. 2006. [A new feromon traps used against insect pests on vegetable crops.] Progress Plant. Prot./Post. Ochr. Roślin, Poznań 46/2/: 363366. [in Polish with English summary]

Ruszkowska I. 1952. [Observations of the biology of Ceuthorrhynchus suturalis Fabr. (Col., Curculionidae).] Ann.Univ. M. Skłodowska-Curie, Lublin, vol. VII (14): 417-471. [in Polish with English summary]

Ruszkowski J.W. 1933. Wyniki badań nad szkodliwą fauną Polski na podstawie materiałów z lat 1919-1930. Roczn. Ochr. Roślin, B 1/1-2/: 1-567. [in Polish]

Ruszkowski J., Preffer J., Krasucki A., Minkiewicz S., Keler S., Strawiński K., Pronin J. 1935. Wyniki badań nad szkodliwą fauną Polski. Roczn. Nauk. Roln. B: Szkodniki roślin 2/2-3/: 1-20. [in Polish]

Rygg T. 1960. [The onion fly (Hylemyia antiqua Meig.). Investigations on its biology and control in Norway.] Medd. St. Plantev 18: 1-56. [in Norwegian with English summary]

Sądej W., Rozmysłowicz R., Sądej W. 2003. [Population of click beetles Elateridae in grey-bran podzolic soil formed by different ways of soil use]. Progress Plant. Prot./Post. Ochr. Roślin, Poznań 46/1/: 300-304. [in Polish with English summary]

Schreier O. 1953. Über Auftreten und Bekämfung der Zwiebelfliege (Hylemyia antiqua Meigen). Pflanzenschutz Berichte, Wien, 10(1-2): 4-13. [in German]

Sionek R. [1998 - Napomyza gymnostoma Loew (Diptera, Agromyzidae) and Oprohinus suturalis F. (Curculionidae, Coleoptera) the important pest of onion in south-eastern Poland.] Ann. Agric. Sci., Plant Prot., 27,1-2: 73-80. [in Polish with English summer]

Sionek R. 2001. Napomyza gymnostoma Loew (Diptera, Agromyzidae) szkodnik roślin cebulowych w południowo-wschodniej Polsce, zagadnienia biologii, ekologii i zwalczania. Praca doktorska, Akademia Rolnicza, Wydział Ogrodniczy Kraków, ss. 121. [in Polish]

Szwejda J. 1982. [Population dynamics and harmfulness of onion maggot (Hylemya antiqua Meig. (Dipt.: Anthomyiidae) on onion]. Rocz. Nauk Roln., 12(1/2): 5771. [in Polish with English summary]

Szwejda J. 1988. Diptera of garlic and ecological observations on dominant species Suillia lurida Meig. (Dipt., Helomyzidae). Acta Hort. Intern. Symposium on Diptera Pests in Veg. Crops. ISHS, Skierniewice, 219: 99-108.

Szwejda J. 1998. [Threat of onion plantations with pests, especially Diptera]. Biul. Warzywn., Skierniewice 48: 57-63. [in Polish with English summary]

Szwejda J. 2003. Diptera occurring on vegetable crops. Integrated control in field crops. IOBC WPRS Bull. 26(3): 113-119.

Szwejda J. 2005a. [Review of pests actually threatening of onion in Poland]. Nowości Warzywnicze/Vegetable Crops News, Skierniewice 40: 53-59. [in Polish with English summary]

Szwejda J. 2005b. Szkodniki zagrażające cebuli ozimej. Ochrona Roślin, 11: 23-25. [in Polish].

Szwejda J. 2006a. [Pest monitoring in the protection of vegetable crops]. Nowości Warzywnicze/Vegetable Crops News 42: 87-98 [in Polish with English summary]

Szwejda J. 2006b. Pest management in ecological production of vegetables in Poland. Ann. Warshaw Agricult. Univ., Horticult. and Landsc. Architect. 27: 5-15.

Tischler W. 1965. Agrarökologie. Veb Gustav Fischer Verlag, Jena, pp. 487. [in German] 
Węgorek W. 1966. Rolnice (Agrotinae) krajobrazu rolniczego. [Cutworms (Noctuidae: Lepidoptera]. Prace Nauk. IOR, Poznań 8/2/: 5-69. [in Polish]

Wiewióra I., Łuczak I. 2001. Atrakcyjność różnych odmian cebuli uprawianej z dymki dla poskrzypki cebulowej. Ogóln. Konf.: "Biologiczne i agrotechniczne kierunki rozwoju warzywnictwa". Instytut Warzywnictwa, 167-168. [in Polish]

Wrzodak R. 2008. Wciornastek tytoniowiec (Thrips tabaci Lind.). In: Fitofagiczna entomofauna cebuli ozimej - szkodliwość gatunków dominujących. Sprawozdanie $\mathrm{z}$ lat 2006-2008, 12.7. Archiwum Instytutu Warzywnictwa, Skierniewice, pp. 3. [in Polish]

Zawirska I. 1994. Wciornastki - Thysanoptera. pp. 145-174. In: Diagnostyka szkodników roślin i ich wrogów naturalnych. Wyd. SGGW, Warszawa, 1-328. [in Polish]

\section{FITOFAGICZNA ENTOMOFAUNA WYSTĘPUJĄCA NA PLANTACJACH CEBULI W POLSCE W LATACH 1919-2007}

Streszczenie
W okresie od 1919 do 2007 roku, na krajowych plantacjach cebuli zarejestrowano występowanie fitofagicznej entomofauny należącej do 37 taksonów reprezentujących 7 rzędów owadów: przylżeńców (Thysanoptera), pluskwiaków równoskrzydłych (Homoptera), pluskwiaków różnoskrzydłych (Heteroptera), motyli (Lepidoptera), chrząszczy (Coleoptera), muchówek (Diptera) oraz prostoskrzydłych (Orthoptera). W obrębie tych grup stwierdzono: 22 gatunki fitofagiczne (phytophagous species) oraz taksony zidentyfikowane do 5 rodzajów - genus (Thrips, Mamestra, Polia, Agrotis, Agriotes) i 3 rodzin - family (Sciaridae, Bibionidae, Tipulidae). Ponadto zebrano 7 gatunków saprofagicznych muchówek z uszkodzonej cebuli w okresie jej zbioru.

Do dominujących gatunków powszechnie występujących we wszystkich rejonach uprawy cebuli należały: śmietka cebulanka (Delia antiqua Meig.), wciornastek tytoniowiec (Thrips tabaci Lind.) chowacz szczypiorak (Ceutorhynchus suturalis Fabr.), wgryzka szczypiorka (Acrolepiosis assectella Zell.) i rolnice (Noctuidae). Liczebność populacji gatunków: poskrzypki cebulowej (Margarita stricticalis L.), błotniszki czosnkówki (Suillia lurida Meig.), miniarki porówki (Napomyza gymnostoma Loew), stwarzała okresowe zagrożenia, szczególnie w południowych rejonach kraju. Na wilgotnych i zasobnych w substancje organiczne glebach notowano okresowe skupiska szkodników glebowych; larw (pędraków) gatunków należących do rodzaju Melolontha (Scarabaeidae), drutowców z rodzaju Agriotes (Elateridae), muchówek (Diptera) z rodziny komarnicowatych (Tipulidae) i leniowatych (Bibionidae).

Stwierdzone zmiany gatunkowe i populacyjne przedstawionych fitofagów pozwoliły na opracowania skutecznych metod ochrony plantacji cebuli. Podstawą do działań ochronnych było monitorowanie pól w oparciu o stale unowocześniany system prognozowania krótko- i długo terminowego (short- and long-term forecasting). 